\title{
MODELS AND SIMULATIONS OF TRANSMISSION OF HYBRID AND ELECTRIC VEHICLES
}

\author{
Milan Bukvić ${ }^{1}$ Živojin Petrović, Blaža Stojanović, Saša Milojević
}

UDC: 629.3.021;621.313

DOI: $10.24874 / m v m .2017 .43 .02 .01$

\begin{abstract}
All systems in the construction of vehicles can be grouped logically, either as a structural system or control system. Structural systems consist of one or more sub-systems, as well as the optional files that define the system. Structural systems do not contain models, but only describe the structure, connecting systems and subsystems. The control systems consist of a model which defines the behaviour of the system and all the files needed to support or calculation of the output value of the system. Models and control systems include mathematical equations that describe the functions of the system or subsystem. Both of these types of systems are arranged in a hierarchical manner in order to define a vehicle that will be simulated. To avoid confusion, the best solution is to replicate the composition of the actual system, as far as possible. For example, small controllers should be grouped with the components they control, at various hierarchical levels wherever possible. Also, only systems that really are in the vehicle should be represented, in other words, there is no need for the unused components or space controllers. In addition to simplifying the construction, this concept will allow easy transfer between users and the system will be fully supported hardware and software, while ensuring effective control of the prototype, according to the needs.
\end{abstract}

KEY WORDS: hybrid and electric vehicles (HEV), transmissions, model simulation, simulation, software

\section{MODELI I SIMULACIJE TRANSMISIJA HIBRIDNIH I ELEKTRIČNIH VOZILA}

REZIME: Svi sistemi u konstrukciji vozila mogu se grupisati logično, bilo kao konstruktivni sistem ili sistem kontrole. Strukturni sistemi se sastoje od jednog ili više podsistema, kao i odgovarajuće datoteke koje definišu sistem. Konstrukcijski sistemi ne sadrže modele, ali opisuju samo strukturu, povezivanje sistema i podsistema. Sistemi kontrole se sastoje od modela koji definiše ponašanje sistema i sve datoteke potrebne za podršku ili proračun izlaznih vrednosti sistema. Modeli i kontrolni sistemi uključuju matematičke jednačine koje opisuju funkcije sistema ili podsistema. Obe ove vrste sistema su raspoređene u hijerarhijskom smislu u cilju definisanja vozila koje će se simulirati. Da bi se izbegla konfuzija, najbolje rešenje je da se oponaša kompozicija stvarnih sistema, koliko je to moguće. Na primer, male kontrolore treba grupisati sa komponentama koje kontrolišu, na različitim hijerarhijskim nivoima gde god je to moguće. Takođe, samo sistemi koji su zaista u vozilu treba da budu modelirani, drugim rečima, nema potrebe za komponentama koje se ne koriste ili za prostorom za kontrolere. Pored pojednostavljenja izrade, ovaj koncept će omogućiti jednostavan prenos između korisnika i sistem će biti u potpunosti podržan hardverom i softverom, istovremeno osiguravajući efektivnu kontrolu nad prototipom, u skladu sa potrebama.

${ }^{1}$ Received December 2016, Accepted April 2017, Published On Line June 2017 
KLJUČNE REČI: hibridna i električna vozila (HEV), transmisije, model simulacije, simulacija, softver 


\title{
MODELS AND SIMULATIONS OF TRANSMISSION OF HYBRID AND ELECTRIC VEHICLES
}

\author{
Milan Bukvić ${ }^{1}$, Živojin Petrović ${ }^{2}$, Blaža Stojanović ${ }^{3}$, Saša Milojević ${ }^{4}$
}

\section{INTRODUCTION}

In addition to the variety of HEV topologies, HEV powertrains make use of more components than conventional vehicles [1]; particularly electric components such as energy storage devices, controllers, power electronics and electric machines. These additional components dynamically interact with the conventional mechanical components. Therefore there are a much larger number of parameters and combinations which need to be analysed in order to optimise a particular powertrain design. Analysis of such a system is difficult due to its multidisciplinary nature and testing through prototyping can be both costly and time consuming [2]. The availability and use of computer modelling and simulation tools is a key component in studying the complexities of HEV powertrain design [3].

Traditionally, many computer simulation models are built during the design lifecycle of a new vehicle. Different models are built for different purposes such as models to study fuel economy, models for controller evaluation, models for optimization or models for design exploration [2]. This leads to the creation of many models of the same system which all need to be maintained and managed.

For conventional vehicle design, even though the complexity of modern vehicles is increasing, many of the systems being modelled are based on well-known and understood previous designs and architectures $[4,5]$.

The availability of existing validated models and expert knowledge of the systems involved is an essential part of the initial development of new designs. With HEVs, however, there is a much smaller and limited amount of prior knowledge and many designs are still at a conceptual phase, meaning that many changes may still occur to the system.

[6]:

The primary reasons for looking at new ways of developing HEV powertrains are

- reducing development time

- exploring new designs

- increased complexity

- higher expectations for reliability and

- reducing the amount of prototype testing needed.

In the software development domain, it has been shown that the time and effort required to build a system increases exponentially with the size and complexity of the

\footnotetext{
${ }^{1}$ Milan Bukvić, Ph.D., student, University of Kragujevac, Faculty of engineering, 6 Sestre Janjić Str., 34000 Kragujevac, Serbia, Milan-bukvic76@gmail.com

${ }^{2}$ Živojin Petrović., University of Defence, Military Academy, Kounicova 65, 66210 Brno-střed, Czechia, petrovic.zivojin.jole@gmail.com

${ }^{3}$ Blaža Stojanović, Ph.D., assist. prof., University of Kragujevac, Faculty of engineering, 6 Sestre Janjić Str., 34000 Kragujevac, Serbia, blaza@kg.ac.rs

${ }^{4}$ Saša Milojević, Mr., University of Kragujevac, Faculty of engineering, 6 Sestre Janjić Str., 34000 Kragujevac, sasa.milojevic@kg.ac.rs
} 
design [7]. It can be argued that the same applies to modelling. The use of traditional modelling methods for exploring different HEV design options, risks reaching its limitations as far as managing the complexity of the design space is concerned [8]. Further, it will be necessary to provide sufficient flexibility to the designer to explore many possibilities in as short a time as possible. This leads to a model maintenance and management problem when considering the number of models that such a process will generate and the potential number of different users that would be involved.

\section{BASIC CONCEPTS AND CLASSIFICATION OF HYBRID AND ELECTRIC VEHICLES}

Hybrid vehicles have been based on two sources of energy - aggregate energy conversion (combustion engine or fuel cell) and the aggregate accumulation of energy produced (batteries or ultracapacitors). Complete drive system comprising: IC (internal combustion) engine, electric generator, electric motor, power converter and the battery pack. The point of the existence of hybrid vehicles is the fact that these vehicles have no problems with the radius of movement, because they use chemical fuel to power combustion engines at the same time are environmentally cleaner and more efficient compared to conventional vehicles, because they use the benefits of electric drive systems. Power installed thermal and electrical machines is greater than the required traction power, and the system itself is much more complex than electric vehicles and conventional vehicles with internal combustion engines [9].

There are two basic configurations of hybrid vehicles: serial and parallel. In addition there is a serial - parallel configuration of a hybrid vehicle, resulting from efforts to consolidate good characteristics and serial and parallel configurations of hybrid vehicles [9].

In serial hybrid vehicle internal combustion engine runs a special generator that supplies the electric traction motor with energy and supplement batteries. Internal combustion engine has been used in the optimal mode, a speed control has been achieved by an electric motor. The existence of the battery and the electric motor provides a reversible (engine) braking, thus increasing vehicle efficiency.

The main features of the serial hybrid vehicles are [9]:

- use a larger battery

- use charging batteries while driving

- batteries can be upgraded and when the vehicle is not in use (external)

- optimize the operation of separating the work of both the speed of the motor vehicle

- electric motor does not idle, which reduces emissions

- does not require a complex transmission vehicles

- use high power IC engine.

Parallel hybrid vehicles are designed so that the wheels driven by the IC engine and an electric motor/generator. IC engine with the vehicle runs in optimal mode, where the electric machine operates as a generator and supplements the battery, when the movement of the lower power output of IC engines, and when you need more power, then electric machine operates as a motor using energy from battery. The point of introducing this concept of hybrid vehicles can be found in the fact that the installed capacity of electric machines smaller, reducing the weight of the vehicle. Instead of separate motors and 
generators, as used herein is only one machine, whose power is less than the power of the traction motor with the serial vehicle size.

The main features of parallel hybrid vehicles are [9]:

- electric motor and IC engine are directly connected to the wheels

- use less battery

- has the ability to charge the battery when the engine is not working IC engine

- faster speeds

- electric motor has a neutral

- installation of components in the vehicle is less flexible

- use medium power IC engine.

There are electric motor and generator to the serial - parallel hybrid vehicle, but with lower power than the pure serial hybrid concept vehicle. According to the needs it is possible to drive only IC engine runs generator or with an electric motor drives the wheels and the generator idle.

The main features of serial - parallel hybrid vehicles are [9]:

- use battery of medium size

- has the rechargeable battery when IC engine works, and when it not works

- faster speeds

- electric motor does not idle

- installation of components in the vehicle is less flexible

- use high power IC engine.

Fully electric vehicles are vehicles for their movements using electrical energy stored in batteries or the battery is obtained from a fuel cell. The drive of the vehicle consists of the following subsystems:

- batteries

- inverter power electronics

- electric motor and

- most often, the mechanical force transmission system.

The electric motor is the only electric machine that has been installed in the towing vehicle subsystem and its strength is equal to the force required to tow.

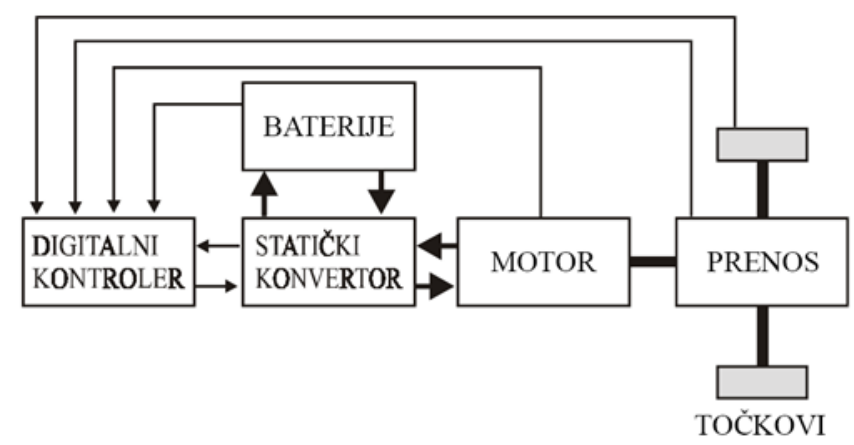

Figure 1 Schematic representation of an electric vehicle [9] 
In the above figure are thin lines displayed information and control connections, while thick lines indicate the energy links in the system. The arrows indicate the direction of movement of information, or electricity. Such vehicles do not emit any exhaust gases and are classified as vehicles with zero emissions. This means that they are environmentally friendly assuming that the careful handling batteries, since certain types of batteries contain highly toxic substances. Lacks of electric vehicles are their relatively poor performance. This primarily applies to a small radius of movement, the relatively poor acceleration and low final speed due to the high weight of the battery. In the case of a large number of vehicles, the vast mass of the battery weight distribution and a bad condition and bad behaviour of the vehicle when cornering.

\section{FUNDAMENTALS OF VEHICLE SYSTEMS MODELLING}

It is important to define the common terms used in modelling. The following definitions have been related to HEV modelling [11]:

1. System: The object or objects we wish to study. In the context of this paper, the system will be an electric or HEV.

2. Experiment: The act of obtaining information from a controllable and observable system by intelligently varying system inputs and observing system outputs.

3. Model: A surrogate for a real system upon which experiments can be conducted to gain insight about the real system. The types of experiments that can be validly applied to a given model are typically limited. Thus, different models are typically required for the same target system to conduct all of the experiments one wishes to conduct. Although there are various types of models (e.g., scale models used in wind tunnels), in this paper, we will mainly discuss about physics-based mathematical models.

4. Simulation: An experiment performed on a model.

5. Modelling: The act of creating a model that sufficiently represents a target system for the purpose of simulating that model with specific predetermined experiments.

6. Simulator: A computer program capable of performing a simulation. These programs often include functionality for the construction of models and can often be used in conjunction with advanced statistical engines to run trade studies, design of experiments, Monte Carlo routines, and other routines for robust design.

\section{MODELLING CONCEPTS}

Powertrain models are traditionally classified as one of the following causal types [2], [12], [13], [14]:

1. Forward facing - Models of this type follow a "cause-effect" calculation process in the direction of the driving vehicles physical power flow. Starting with a demand set point, usually in the form of an accelerator signal, torque demands for each subsystem can be calculated in a forward direction until the resultant force at the wheel is found and from this the vehicle speed. Additionally driver models can incorporate logic for steering commands, gear changes and clutch actuation. These 
models are more representative of the real world system, making use of measurable variables such as torque inputs, brake and accelerator demands. This makes them well suited to controller development and testing, in particular real-time control strategies [2]. Also it is possible to include transient subsystem models for studying the system dynamics [15].

2. Backward facing - These models calculate in the opposite direction to the power flow. In other words, calculations are performed backwards from the wheels to the power sources in an "effect-cause" manner. By imposing a drivecycle, tractive effort at the wheels can be calculated and continuing to move backward through each powertrain subsystem until the energy required from the input sources can be determined. These models are generally computationally faster than forward facing models and are therefore useful for architectural studies and optimization routines that require many iterations of relatively longer cycle times [2, 17]. Steady-state efficiency and lookup tables are generally used to account for subsystem losses and hence these models tend not to take dynamic effects into account [16].

3. Combined backward/forward - It is possible to combine both approaches by iterating backward simulations to achieve a target setpoint [14]. This approach requires a forward and backward model for each component. First a back-wards simulation determines component efficiencies and operating limits, and then the forward facing models are used for a forwards simulation using the previously calculated efficiency and limit values [18]. The ADVISOR simulation software uses this "hybrid" approach, more details on the way this is implemented are given in [16]. Using this type of model allows for faster simulation than the standard forward facing approach since it is possible to make use of larger time-steps and lower orders of integration [16, 19]. Further, designing control algorithms suitable for usage on the real-world system is made difficult by this modelling method [20].

\section{HEV MODELLING USING ADVISOR}

ADvanced VehIcle SimulatOR (ADVISOR) is a modelling and simulation tool developed by U.S. National Renew-able Energy Laboratory (NREL) [21], [22]. It can be used for the analysis of performance, fuel economy, and emissions of conventional, electric, hybrid electric, and fuel cell vehicles. The backbone of the ADVISOR model is the Simulink block diagram shown in Fig. 2, for a parallel HEV as an example.

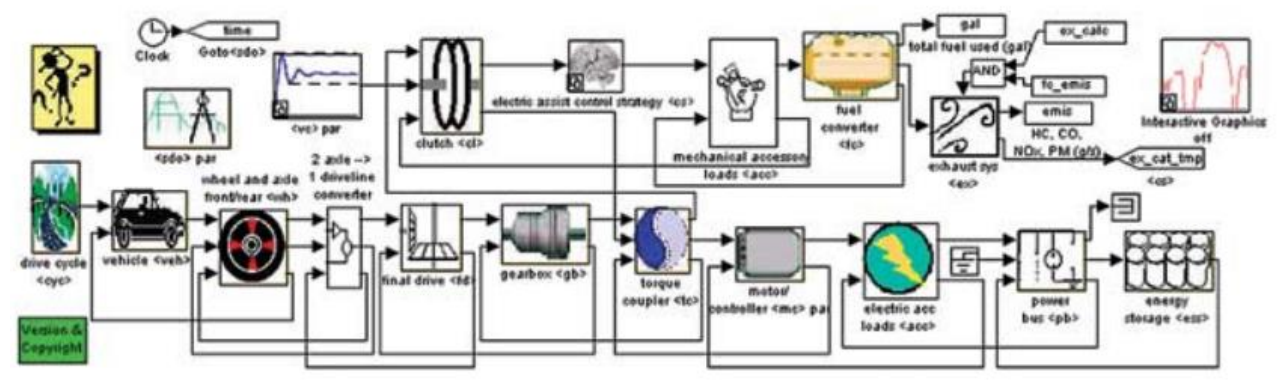

Figure 2 Block diagram of parallel HEV in ADVISOR [21] 
Each subsystem (block) of the block diagram has a Matlab file (m-file) associated with it, which defines the parameters of that particular subsystem. The user can alter both the model inside the block as well as the m-files associated with the block to suit the modelling needs. For example, the user may need a more precise model for the electric motor subsystem. A different model can replace the existing model as long as the inputs and the outputs are the same. On the other hand, the user may leave the model intact and only change the $\mathrm{m}$-file associated with the block diagram. ADVISOR provides modelling flexibility for a user.

The program also allows for the linear scaling of components. For an IC engine, this means linear scaling of the torque to provide the required maximum power. This type of scaling is valid only in the neighbourhood near the actual parameter where the efficiency map for a slightly larger or smaller component would not change drastically.

In the latest version of ADVISOR, the functionality of the software was improved by allowing links to other software packages such as Ansoft Simplorer [23] and Synopsys Sabre [24]. These powerful software package sallow for a more detailed look at the electric systems of the vehicle.

\section{HEV MODELLING USING PSAT}

The Powertrain System Analysis Toolkit (PSAT) is a state-of-the-art flexible simulation software developed by Argonne National Laboratory and sponsored by the U.S. Department of Energy (DOE) [25]. PSAT is modelled in a MATLAB/Simulink environment and is set up with a graphical user interface (GUI) written in $\mathrm{C}++$, which make sit user friendly and easy to use. Being a forward-looking model, PSAT allows users to simulate more than 200 pre-defined configurations, including conventional, pure electric, fuel cell, and hybrids (parallel, series, power split, series-parallel). The large library of component data enables users to simulate light, medium, and heavy-duty vehicles.

The level of details in component models can be flexible, e.g., a lookup table model or high-fidelity dynamic model can be used for a component, depending on the user's simulation requirements. To maintain modularity, every model must have the same number of input and output parameters. The use of quasi-steady models and control strategies including the propelling, braking, and hifting strategies in PSAT sets it apart from other steady-state simulation tools like ADVISOR. This feature makes PSAT predict fuel economy and performance of a vehicle more accurately. Its modelling accuracy has been validated against the Ford P2000 and Toyota Prius. PSAT is designed to co simulate with other environments and is capable of running optimization routines. Hardware-in-the-loop (HIL) testing is made possible in PSAT with the help of PSAT-PRO, a control code to support the component and vehicle control [25].

As an application example, PSAT is used to optimize a parallel HEV for maximum fuel economy on a composite driving cycle. Four global algorithms, Divided RECTangle (DIRECT), Simulated Annealing (SA), Genetic Algorithm (GA), and Particle swarm optimization (PSO) are used in the model-based design optimization [26]. The vehicle model ISG (available in the PSAT model library) has been chosen for this optimization study. This vehicle is a two-wheel-drive starter-alternator parallel configuration with manual transmission. The basic configuration of the parallel HEV used for simulation is illustrated in Fig. 3. 


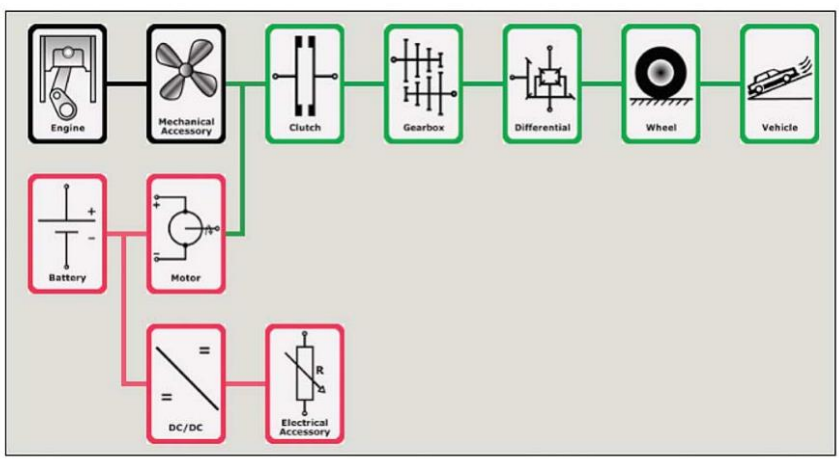

Figure 3 Configuration of selected HEV in PSAT [26]

The driving cycle is composed of city driving represented by FTP-75 (Federal Test Procedure) and the highway driving represented by HWFET (Highway Fuel Economy Test).

\section{PHYSICS-BASED MODELLING}

PSAT and ADVISOR are based on experiential models in the form of look-up tables and efficiency maps. The accuracy of these tools may not be good enough for vehicles operating under extreme conditions. For detailed dynamic modelling and simulation of HEV system, physics-based modelling is needed. VTB, PSIM, Simplorer, VElph are good examples of physics-based modelling tools, where the state variables of a component or subsystem are modelled according to the physical laws representing the underlying principles. The resulting model is a function of device parameters, physical constants, and variables. Such physics-based models can facilitate high fidelity simulations for dynamics at different time scales and also controller development.

The most useable technique of the physics-based modelling is Resistive Companion Form (RCF) [27, 28]. The RCF method originates from electrical engineering but is suitable for multi-disciplinary modelling applications such as hybrid powertrain.

Using the Resistive Companion Form modelling technique, we can obtain highfidelity physics-based models of each component in modular format. These models can be seamlessly integrated to build a system simulation model suitable for design. Just as a physical device is connected to other devices to form a system, the device can be modelled as a block with a number of terminals through which it can be interconnected to other component models, as shown in Fig. 4. Each terminal has an associated across and a through variable. If the terminal is electrical, these variables are the terminal voltage with respect to a common reference and the electrical current flowing into the terminal, respectively. Notice that the concept of across and through variables in RCF is similar to the effort/flow concepts used in ADVISOR and PSAT. 


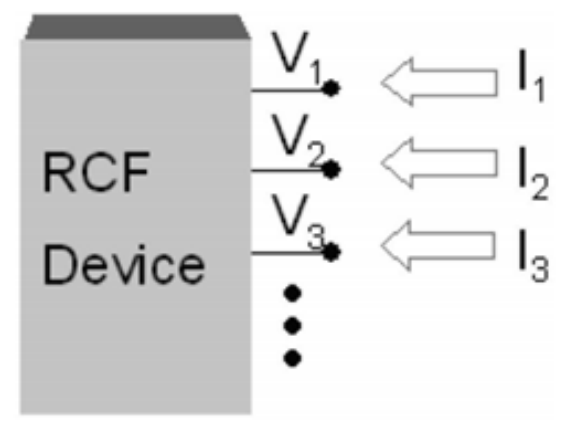

Figure 4 Physics-based RCF modelling technique [29]

After all the powertrain components are modelled in RCF, they can be integrated into one set of algebraic equations by applying the connectivity constraints between neighbouring modular components, which can then be solved to get system state variables.

\section{CONCLUSIONS}

With the advent of powerful computing, development of computational methods, and advances in software-in-the-loop (SIL) and hardware-in-the-loop (HIL) modelling and simulations, it is now possible to study numerous iterations of different designs with the combinations of different components and different topology configurations. HIL is becoming increasingly important for rapid prototyping and development of control system for new vehicles.

With the ever more stringent constraints on energy resources and environmental concerns, HEV will attract more interest from the automotive industry and the consumer. Although the market share is still insignificant today, it can be predicted that HEV will gradually gain popularity in the market due to the superior fuel economy and vehicle performance. Modelling and simulation will play important roles in the success of HEV design and development.

\section{REFERENCES}

[1] Treffnger P., Baur M., Braig T., Dittus H., and Ungethüm J.:"Modelling of Alternative Propulsion Concepts Applying Modular Object-Oriented Simulation Techniques" in Proceedings of the 23rd International Electric Vehicle Symposium (EVS-23), Anaheim, Dec. 2007, California, USA.

[2] Gao D. W., Mi C., and Emadi A.:"Modelling and Simulation of Electric and Hybrid Vehicles", Proc. IEEE, vol. 95, no. 4,2007., pp. 729-745.

[3] Wolfson R. and Gower J.: "The Role of Computer Modelling and Simulation in Electric and Hybrid Vehicle Research and Development", IEEE Trans. Veh. Technol., vol. 32, no. 1, 1983., pp. 62-73.

[4] Jennings M. and Rangan R.: "Managing complex vehicle system simulation models for automotive system development", J. Comput. Info. Sci. Eng.,vol. 4, no. 4, 2004., pp. 372-378. 
[5] Tsou P., Rose L., Che J., Zaremba A., and Jennings M.: "Challenges of Creating Complex Integrated Vehicle System Models" in Proceedings of Math-Works Automotive Conference (MAC 2007), Math-Works, June 2007., Dearborn, Michigan.

[6] Schyr C. and Gschweitl K.: "Model-based Development and Calibration of Hybrid Powertrains" in SAE Technical Papers, no. 2007-01-0285. Society of Automotive Engineers, 2007.

[7] Khosha S. and Abnous R., Object Orientation: "Concepts, Analysis and Design, Languages, Databases, Graphical User Interfaces, Standards", 2nd ed. New York: John Wiley \& Sons, Inc., 1995.

[8] Eborn J., Pedersen L., Haugstetter C., and Ghosh S.: "System Level Dynamic Modelling of Fuel Cell Power Plants" in Proceedings of the 2003 American Control Conference, vol. 3, June 2003., pp. 2024-2029.

[9] Ehsani M., Gao Y., Gay S. E., Emadi A.:"Modern electric, hybrid electric, and fuel cell vehicles: fundamentals, theory, and design", Texas A\&M University, USA, 2005.

[10] Hermance D., Sasagi S.: "Hybrid electric vehicle take to the street", IEEE Spectrum, Vol. 35, No. 11, 1998.

[11] Fritzson P.: "Principles of Object Oriented Modelling and Simulation With Modelica 2.1. Piscataway", NJ: IEEE Press, 2004.

[12] Mierlo J. Van, P. Bossche Van den, and Maggetto G.: "Models of energy sources for EV and HEV: fuel cells, batteries, ultracapacitors, flywheels and engine-generators" in Journal of Power Sources, vol. 128, no. 1, 2004., pp. 76-89.

[13] Yunpeng C., Xiaomin S., and Peifa J.: "Forward-facing Modelling for an Electric Vehicle Powertrain" in The 20th International Electric Vehicle Symposium (EVS-20), Nov. 2003., Long Beach, CA.

[14] Mierlo J. Van and Maggetto G.: "Vehicle simulation program: a tool to evaluate hybrid power management strategies based on an innovative iteration algorithm" in Proc. IMechE Part D: Journal of Automobile Engineering, vol. 215, no. 9, 2001., pp. 1043-1052.

[15] Markel T., Brooker A., Hendricks T., Johnson V., Kelly K., Kramer B., O'Keefe M., Sprik S., and Wipke K.: "Advisor: a systems analysis tool for advanced vehicle modelling", Journal of Power Sources, vol. 110, no. 2, Aug. 2002., pp. 255 - 266.

[16] Wipke K. B., Cuddy M. R., and Burch S. D.:"Advisor 2.1: a user-friendly advanced powertrain simulation using a combined backward/forward approach", IEEE Trans. Veh. Technol., vol. 48, no. 6, Nov. 1999., pp. 1751-1761.

[17] Cacciatori E.: "Advanced Control Concepts for a Parallel Hybrid Powertrain with Infinitely Variable Transmission" Ph.D. dissertation, Cranfield University, 2007, Cranfield.

[18] Mierlo J. Van, Maggetto G. and Bossche P. Van den: "Simulation methodologies for innovative vehicle drive systems" in 11th International Power Electronics and Motion Control Conference (EPE-PEMC'2004), Sept. 2004, Riga, Latvia.

[19] Wilkins S. and Lampérth M.: "The Development of an Object-Oriented Tool for the Modelling and Simulation of Hybrid Powertrains for Vehicular Applications" in SAE Technical Papers, no. 2003-01-2249. Society of Automotive Engineers, 2003.

[20] Markel T. and Wipke K.: "Modelling grid-connected hybrid electric vehicles using advisor" in Proc. of the 16th Annual Battery Conf. Applications and Advances, 2001., pp. 23-29.

[21] Wipke R K. B., Cuddy M. R., and Burch S. D.: "ADVISOR 2.1: A user-friendly advanced powertrain simulation using a combined backward/forward approach", IEEE Trans. Vehicular Technol., vol. 48, no. 6,Nov. 1999., pp. 1751-1761. 
[22] Markel T., Brooker A., Hendricks T., Johnson V., Kelly K., Kramer B., O’Keefe M., Sprik S., and Wipke K.: "ADVISOR: A systems analysis tool for advanced vehicle modelling" J. Power Sources, vol. 110, no. 2, Aug. 2002., pp. 255-266.

[23] Ansoft Simplorer Website. [Online]. Available: http://www.ansoft.com/.

[24] Saber Website. [Online]. Available: http://www.synopsys.com/saber/.

[25] PSAT Documentation. [Online]. Available: http://www.transportation.anl.gov/ software/PSAT/.

[26] Gao W. and Porandla S.: "Design optimization of a parallel hybrid electric powertrain" in Proc. IEEE Vehicle Power Propulsion Conf., Chicago, IL, Sep. 2005, pp. 530-535.

[27] Gao W., Solodovnik E., and Dougal R.: "Symbolically-aided model development for an induction machine in Virtual Test Bed" IEEE Trans. Energy Conversion, vol. 19, no. 1, Mar. 2004., pp. 125-135.

[28] VTB Website. [Online]. Available: http://vtb.ee.sc.edu/.

[29] Wenzhong D. Gao, Mi C., Emadi A.:"Modelling and Simulation of Electric and Hybrid Vehicles", IEEE Xplore, vol. 95, no. 4, April, 2009. 